\title{
OVER VERSCHILLENDE SOORTEN EVENWICHTEN EN DE CONJUNCTUURBEWEGING.
}

\author{
Door J. TINBERoEN.
}

1. In dit opstel worden enige beschouwingen geboden over de verschillende soorten economische evenwichten. De aanleiding daartoe vormen de uiteenlopende opvattingen die men hier en daar in de literatuur aantreft omtrent de plaats der evenwichtsposities in de verklaring der conjunctuurbewegingen. Onder meer bestaan de volgende twee opvattingen die elkaar mogelijkerwijze tegenspreken: a) de conjunctuurbeweging is een schommelende beweging on cen evenwichtspositie heen; b. zij is een beweging tussen twee evenwichten. In geval a) denkt men zich dus een evenwichtspositie ergens tussen de twee uiterste standen van het conjunctuurverloop; in geval b) denkt men zich twee evenwichtsposities die met deze uiterste standen min of meer samenvallen. De eerste opvatting ligt ten grondslag aan de meeste theorieën van de conjunctuurbeweging, zij het de ene maal op veel meer uitgesproken wijze dan de andere maal; de vele termen met de voorvoegsels onder- en over-waarin men zijn gedachten pleegt te formuleren $\mathrm{zijn}$ er aanwijzingen van. Zeer concreet is de opvatting van het evenwicht "ergens in het midden" tot uitdrukking gekomen in enkele econometrische modellen van het conjunctuurverloop. (Men zou zich overigens vergissen als men meende dat de econometrische analyse noodzakelijkerwijze tot deze zienswijze moet voeren). De opvatting van de evenwichten ,aan de uitersten" komt vrij duidelijk tot uiting in enkele geschriften van GOUDRIAAN ${ }^{\boldsymbol{1}}$ ).

2. Bij nader onderzoek van elk dezer beide opvattingen blijkt dat beide een aantal punten onopgehelderd laten, waardoor een

1) J. Goudriaan, De berekening van den omvang der werkloosheid als gevolg van prijsdaling in een gesloten economisch miliet, De Economist 83 (1934), blz. 849.

Econ. 1943 
keuze of een synthese bemoeilijkt wordt. Wij willen allereerst trachten de laarbij rijzende kwesties enigszins systematisch te behandelen. Om te beginnen moet daarbij het begrip evenwicht, zoals dat in de economie te verstaan is, worden gememoreerd. Een evenwichtstoestand is een toestand, dic zich zonder ingrijpen l'an buiten kan handhaven.

Het staat ran te roren gecmszins last dat or crenuichtstoestanden bestaan. Het begrip hoult in dat alle grootheden die de toestand beschrijven constant kunnen blijven. Er zijn een aantal economische modellen te bedenken, waarvoor deze eis een tegenspraak in zichzelf betekent. Beschouwt men een model, waarin de netto-investeringsbedrijvigheid steeds een van nul verschillende omvang heeft, dan kan deze bedrijvigheid weliswaar een constante grootte hebhen, doch dan volgt daaruit een stijging in de tijd van de totak kapitaalgocderenvoorraad. Deze laatste kan slechts dan een constante waarde in de tiju bezitten, wanneer de investeringsbedrijvigheid de waarde nul heeft. In dergelijke modellen is een evenwichtstoestand in de strikte zin van het woord niet mogelijk. Doch bij benadering wel, wanneer men de groei van de kapitaalgoederenvoorraad verwaarloost. Wij willen dat, in navolging van velen, in ons volgend betoog doen.

De bepaling van de evenwichtstoestand van cen bepaald economisch stelsel (een markt, een groep van markten, een volkshuishouding) kan geschieden wameer dat stelsel op de wijze van de statische economie beschreven is. Concreet gezegd: in het geval van én markt kan het evenwicht worden bepaald wanneer men de statische vraag- en aanbodcurve kent; in het geval van ingewikkelder stelsels de overeenkomstige — talrijkere - relaties van statischo aard die ter beschrijving nodig zijn.

3. De evenwichtspositie handhaaft zich, zolang er geen storende invloed van buiten optreedt. Wat gebeurt er echter, wanneer zo'n storing zich voordoet? Er kumnen verschillende dingen gebeuren; en dienovereenkomstig onderscheidt men verschillende soorten 'renwichton. De bekende onderscheiding is die tussen stabicle en labicle evenwichten. Van een stabiel evenwicht spreekt men, wanneer de beweging die na verstoring intreedt, naar dat evenwicht toe gericht is, zodat het opnieuw bereikt wordt. Van een labiel evenwicht, wanneer die beweging van het evenwicht af gericht is, waardoor dit laatste niet meer bereikt wordt. Wij willen deze 
indeling nader bezien en menen dat een onderscheiding van aanmerkelijk meer soorten cvenwichten gewenst is. Zoveel staat echter reeds vast, dat het daarbij gaat on de bewegingen die het beschouwde economische stelsel vertoont na cen gegeven evenwichtsverstoring. D.w.z. dat men om de aard van een evenwicht te leren kennen de aard van die bewegingen nader moet leren konnen of m.a.w. dat men daartoe de bewegingsleer moet gebruiken. Het is nict mogelijk om do naturr van een cvenwicht to liren kenten uit statische gegevens allew. Ook wanneer men zou menen dat dat mogelijk is, zal blijken dat men in feite toch bepaalde veronderstellingen heeft gemaakt over de dynamica van het beschouwde stelsel. Dit laatste is b.v. meestal het geval, wanneer num in de leerboeken de stelling verdedigd vindt dat het evenwicht op een enkelvoudige - door een vraag- en een aanbodlijn beschreven - markt stabicl is wanneer slechts de helling van de aanbodlijn t.o.v. de p-as algebraisch sterker is dan die van de vraaglijn. Zoals ik elders heb uiteengezet ${ }^{2}$ ), komt men tot andere stellingen hieromtrent, wanneer men een andere dynamica van de markt aanneemt dan in bedoelde leerboeken stilzwijgend wordt gedaan, met name, wanneer men de dynamica volgens het spinneweb theorema aanneemt.

Wij dienen dus, on een beter inzicht in de natuur der evenwichten te verkrijgen, de bewegingsleer nader te bestuderen. Wij zullen daarop slechts zover ingaan als voor ons betoog noodzakelijk is. Het zal daarbij blijken, dat reeds de eenvoudigste hypothesen omtrent de beweging van economische stelsels tot een merkwaardige rijkdom van mogelijkheden voeren, waardoor het niet raadzaan is verder te gaan alvorens het empirisch onderzoek heeft geleerd welke der mogelijke gevallen zich in de werkelijkheid voordoen.

4. Elke beweging van een economisch stelsel vindt zijn oorsprong in een afwijking van de evenwichtsstand die op welke wijze dan ook gegeven is. Wanneer er nl. geen afwijking van het evenwicht was, zou er, krachtens de definitie van evenwicht, geen beweging optreden. De meest gewone voorbeelden van dergelijke afwijkingen zijn die waarbij een onverwachte oogstopbrengst, een politieke maatregel, een nieuwe technische vinding

2) ]. Tinbergen, Indifferente en labiele evenwichten in economische stelsels, De Economist 10 (1941), blz. 561 e.v. 
of iets dergelijks zijn invloed doet gelden. Het verdere verloop van de economische toestand, totdat er opnieuw een uitwendige storing optreedt, welk verloop wij als ,endogene beweging" zullen aanduiden, wordt nu bepaald door de reacties der economische subjecten op de eerste evenwichtsverstoring. Zo zal een onverwacht grote oogst leiden tot een groter aanbod; ten einde dit grotere aanbod te kunnen plaatsen zullen de aanbieders een lagere prijs vragen. Deze lagere prijs zal voeren tot enerzijds een hogere vraag, anderzijds een lagere productie in een volgend seizocn enz. Er ontwikkelt zich wat tegenwoordig nog al eens genoemd wordt een ,sequence", een opeenvolging, van elkaar achtereenvolgens bepalende toestanden. Iedere nieuwe toestand wordt, dit is het kenmerkende van de dynamica, bepaald gedacht door de voorafgaande ontwikkeling; zolang er althans geen nieuwe storingen optreden. Zou men dit niet aannemen, d.w.z. zou men de opeenvolgende toestanden als van elkaar onafhankelijk beschouwen, dan zou men het bestaan van een economische dynamica ontkennen; zou men aannemen dat de reacties oneindig snel plaats vinden, dan zou men eveneens het bestaan van een dynamica ontkennen, want dan zou het evenwicht onmiddellijk weer worden bereikt en dus de statica voldoende zijn.

5. De verschillende logische vormen van dynamische theorie die mogelijk zijn laten zich nu rangschikken naar de ingewikkeldheid hunner veronderstellingen. Het eenvoudigste zijn wel de theorieën die aannemen dat clkc volgende toestand slechts afhangt van één voorafgaande en wel de onmiddellijk voorafgaande. In cenvoud volgend is de klasse der theorieën die aanneemt dat elke toestand afhangt van de twee voorafgaande toestanden, enz. Een en ander veronderstelt dat wij werken met een zekere tijdseenheid van eindige omvang, gedurende welke wij de toestand als onveranderd beschouwen.

Wij willen deze wel zeer abstracte uiteenzetting onmiddellijk verduidelijken aan een concreet voorbeeld. Voor de studie van de conjunctuurverschijnselen zijn zeer belangrijke grootheden het totale in een bepaalde als eenheid van tijd gekozen periode verdiende inkomen $Y$ van alle subjecten en het in die periode uitgegeven bedrag (de uitgaven $U$ ), waarbij wij denken aan alle uitgaven, zowel voor consumptie als voor investeringen. Wanneer wij een gesloten volkshuishouding beschouwen en als inkomen 
beschouwen de waarde van alle voortgebrachte finalgoederen voor consumptie en investering, dan kunnen wij stellen dat huinkomen $Y_{t}$ in een periode $t$ wordt bepaald door de totale uitgaven $U_{t}$ in diezelfde periode aan consumptie- en investeringsgoederen. De uitgaven $U_{t}$ zullen daarentegen bepaald worden door het inkomen in een of meer voorafgaande perioden. In het eenvoudigst denkbare geval zullen die uitgaven afhangen van het inkomen $Y_{t-1}$ in de onmiddellijk voorafgaande periode $t-1$. Zij behoeven daaraan overigens nog niet gelijk te zijn. Er kan tussen $Y_{t}-1$ en $U_{t}$ een verband bestaan op de wijze waarop Keynes dit aangeeft voor de consumptieve uitgaven; naar analogie zou men kunnen spreken van een zekere ,propensity to spend". Het verband kan grafisch worden voorgesteld door een curve die $U_{t}$ als functie van $Y_{t-1}$ weergeeft; het cenvoudigst denkbare geval dat waarschijnlijk met de realiteit binnen zekere grenzen vrij goed overeenkomt - is dat waarbij deze curve een rechte lijn is, die echter niet door de oorsprong behoeft te gaan. De helling van deze rechte lijn is de marginale propensity to spend (de marginale bestcdingsquote).

6. Door de twee aangenomen relaties zijn de bewegingen van het zeer eenvoudige economische stelsel dat wij er mee beschrijven geheel bepaald. Grafisch wordt dit verduidelijkt door fig. 1,
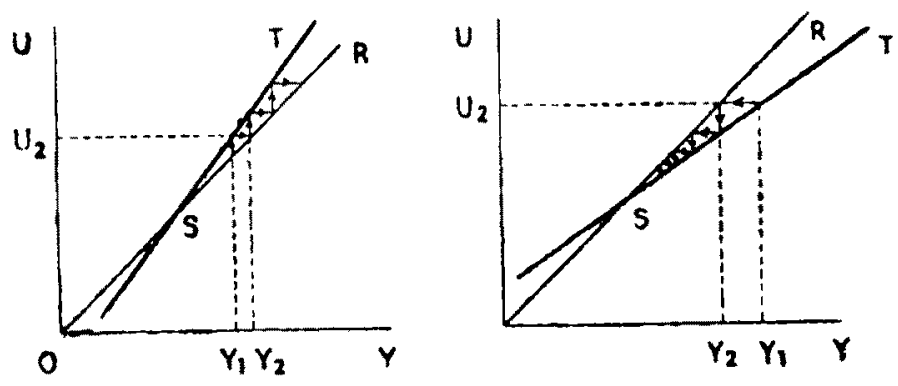

Fig. 1 .

waarin langs de horizontale as de $Y$, langs de verticale as de $U$ is afgezet. Uit een gegeven aanvangswaarde van $Y$, zeg $Y_{l}$, volgt nu het bedrag der uitgaven gedurende de volgende tijdseenheid, $U_{2}$; men leest ze af langs de lijn ST. Uit de gevonden waarde voor $U_{2}$ volgt de waarde van $Y_{2}$, die daaraan gelijk is. In de grafiek kunnen wij dit bereiken door uit $U_{2}$ een horizontale lijn te 
trekken, totdat de lijn SR gesneden wordt, die onder een hoek van $45^{\circ}$ met de beide assen loopt. Op deze wijze kunnen wij voortgaan. Er volgt een oneindige reeks van waarden van $U$ en $Y$ uit, die de beweging van het stelsel bepaait. In het gestclde eenvondige geval zijn er slechts twee mogelijkheden. De beweging kan gericht zijn naar het snijpunt der twee lijnen ST en SR toe; of daarvanaf. Dit snijpunt $S$ representeert, evenals bij de grafische voorstelling van de enkelvoudige markten, een evenwichtspunt; indien de beweging nar $S$ toe gericht is, wen stabiel, indion zij daarvandaan gericht is, een labiel evenwicht. Welke van de twee gevallen zich zal voordoen is klaarblijkelijk afhankelijk van de helling van de lijn ST, d.w.z. van de marginale bestedingsquote; is deze groter dan cen, dan is het evenwicht labiel; is zij kleiner dan één, dan is het stabiel. Het eerste geval betekunt dat een inkomensverhoging leiclt tot een verhoging der uitgaven clie groter is; het tweede geval, dat een inkomensverhoging leidt tot een verhoging der uitgaven van geringere omvang. In het grensgeval waarbij de beide lijnen zouden samenvallen hebben wij met en indifferent evenwicht te maken. Het evenwichtspunt $S$ willen wij, ter onderscheiding van verderop nog te noemen evenwichten, het KEYNES-evenwicht noemen. Het is gekenmerkt door gclijkhcid l'an inkomen en uitgaven, d.w.z. door een bedrag mul aan nettohoarding of -dishoarding.

Het aantal der mogelijkheden wordt reeds veel groter wanneer wij niet slechts de inkomens in de onmiddellijk voorafgaande periode $t-1$, doch in de twee voorafgaande perioden $t-1 \mathrm{ch}$ $t$ - 2 als bepalend voor de uitgaven in de periode $t$ beschouwen. Daarbij moet men niet alleen denken aan een invloed van het inkomen in elk dier perioden afzonderlijk, doch b.v. ook aan een invloed van het verschil tussen het inkomen in de periode $t-1$ en de periode $t-2$, d.w.z. aan de mogelijkheid dat de stijging of de daling van het inkomen van invloed is op de uitgaven. Wij komen op de verschillende bewegingsvormen die onder deze omstandigheden kumnen optreden nog nader terug. Vermelden wij reeds, dat zich nu ook periodicke bewegingen kunnen voordoen, d.w.z. bewegingen die zich steeds herhalen. Bij zodanige beweging kan men noch spreken van een naderen van het evenwicht noch van een zich verwijderen daarvan. Dat wil zeggen dat wij aan onze soorten evenwichten een nieuwe soort moeten toevoegen. Wij 
stellen voor om te spreken van scmi-stabicle evenwichten. Behalve zuiver-periodieke bewegingen zijn ook mogelijk gedcmpte periodicke bewegingen. Daarbij wordt de schommelwijdte voortdurend geringer; zodat tenslotte wel exn nadering van het evenwicht plaats vindt. In dit geval is het evenwicht wel stabiel. Tenslotte komen er schommelende bewegingen voor, waarbij de schommelwijite steeds groter wordt; men zegt, dat zij anti-demping bezitten. In doze gevallen is het evenwicht naar onze smak labiel, doch over deze uitbreiding van het begrip valt te twisten.

8. Tot belangrijke nicuwe gezichtspunten kont men, wanneur men de mogelijkheid introduceert van het bestaan van noer dan cin evenwichtstoestand. Op leze meervoudige evenwichton is in dit tijdschrift reeds gewezen door J. G. KoOpmans"). Indien do beide curven van fig. 1, zoals door ons werd veronderstuld, rechte lijnei zijn. zal er maar cen evenwicht zijn; het anntal suijpunten kan echter hoger worden, wanneer een van beide gekromd is of wannecr beide dat zijn. Wiskundig gesproken bepaalt de graad der curven het aantal snijpunten dat -- behoulens bijzondure sevallen zoals het samenvallen der curven - ten hoogste kan optreden. Waar het ons echter op aan komt is, of er redenen ziju on te verwachten dat in de werkelijkheid meer dan éen snijpunt zal optreden.

Zulke redenen zijn or inclerdaad; un zij komen zeer seherp tot nitelrukking in de beschouwingen van GournRAAN") in dit tijelschrift over het ontstaan van werkloosheid. Wij brengen deze beschouwingen hier tot een icts envoudiger gedaante terug, die past bij onze opzet, zonder dat het essuntiele wordt aangetast. Daartoe denken wij ons overigens nu onze figuur 1 veranderd in dier voege dat er gesproken wordt van rëel inkomen en rële uitgaven. De reole uitgaven worden bepaald gedacht door het reële inkomen in voorafgaande perioden; zij bepalen op hun beurt de onvang der productie - zijn daanee cenvoudig gelijk te stellen, indien wij aannemen dat alle productie op bestelling geschiedt. De onvang der productie zal nu naar boven begrensel zijn door de capaciteit van het productieapparaat. Is deze bercikt, dan zal een verdere (denkbeeldige) stijging van het inkomen niet

3) J. G. Koopmans, De mogelikheid van meervoudig econonisch evenwicht, De Economist 81 (1932), biz. 679,766 en 841.

t) T.a.p. 
tot een overeenkomstige stijging van de reële uitgaven ofwel de productie kunnen leiden.

Ook aan de onderzijde is er een zekere begrenzing. Er is een zeker minimum aan uitgaven nodig voor het in stand houden van het leven der mensen en voor het instandhouden van het productieapparaat. Ook wanneer het inkomen daalt onder dit bedrag, zullen deze uitgaven toch gedaan worlen; desnoods door het aangaan van schulden. De lijn ST verkrijgt daarmee de vorm als aangegeven in figuur 2.

Deze vorm is hier in vereenvoudigde gedaante weergegeven, $n 1$. door drie segmenten van rechte lijnen. In de realiteit zal de overgang van de ene naar de andere faze geleidelijker plaats hebben; de productiecapaciteit is niet in alle takken op hetzelfde ogenblik bereikt. Het noodzakelijke minimum verschilt voor verschillende personen en takken van bedrijf; het wordt daarenboven niet op hetzelfde ogenblik bereikt. Wij zien daarvan voorlopig af en nemen dus aan dat de overgang wel abrupt is. Er zijn nu, ondanks de eenvoudige gedaante der curven, drie snijpunten mogelijk, zoals in fig. 2A tot uitdrukking komt. De twee uiterste punten zijn die van volle bezetting en van het noodzakelijke minimum; wij zullen ze de GoudriaAN-punten noemen; in dit geval ligt daartussen in het evenwicht van KEYNES. Het is echter ook mogelijk dat de figuur een der gedaanten van de overige afdelingen van fig. 2 aanneemt. Daarbij ontbreekt het evenwicht van KeYnes of valt, als grensgeval, met een der beide andere samen (dit laatste doet zich voor in de twee laatste afdelingen van fig. 2).
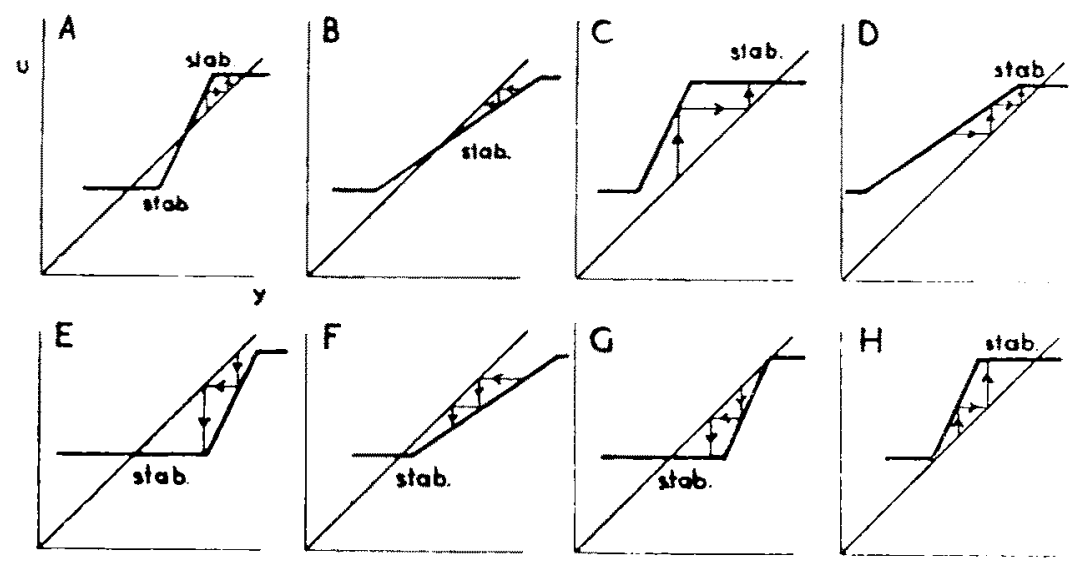

Fig. 2. 
9. Het loont de moeite na te gaan, welke de aard dezer verschillende evenwichten kan zijn in elk der mogelijke gevallen van dynamische reacties die wij in het bovenstaande hebben besproken, d.w.z. wanneer de uitgaven bepaald worden door de inkomens in één resp. in twee voorafgaande perioden. De mogelijkheden voor de eenvoudigste dynamische reactie zijn weergegeven in fig 2 . Wanneer er drie evenwichten zijn (fig. 2A) zijn de uiterste beide stabiel. In fig. $2 B$ is er slechts één evenwicht, in het midden, dat stabiel is. Ontbreekt het middelste evenwicht, dan is er in het algemeen maar én evenwicht, dat steeds stabiel is (fig. $2 \mathrm{C}-2 \mathrm{~F}$ ). Doet zich juist het grensgeval voor, dan krijgen wij met een nieuw soort evenwicht te maken, waarop de aandacht is gevestigd door KAinOR "). Wanneer door een toevallige oorzaak het evenwicht verbroken wordt, is de reactie een andere al naarmate een storing naar boven dan wel een naar beneden heeft plaats gevonden. Is in fig $2 \mathrm{G}$ b.v. het inkomen even lager dan met het bovenste evenwicht overeenkomt, dan treedt een beweging van dat evenwicht af op; hetzelfcle, wanneer de productie door toevallige oorzaken even lager is dan de evenwichtsproductie. Wanneer echter het inkomen even hoger zou zijn dan met het evenwicht overeenkomt, clan herstelt zich het evenwicht. Kennelijk is dit evenwicht voor schokken naar beneden labiel, voor schokken naar boven daarentegen stabiel. Wij zullen spreken van een gemengd evenwicht. Op zichzclf is deze vorm van evenwicht een voor de verklaring van de conjunctuurbeweging zeer bruikbaar instrument. In de uiterste standen van de conjunctuur heeft men inderdaad te maken met zodanige situaties dat schokken naar de ene kant een geheel andere uitwerking hebben dan schokken naar de andere kant. Doch de bewegingsbeelden bij de hier veronderstelde eenvoudige dynamica zijn toch niet in voldoende overeenstemming met het conjunctuurverloop om dit te kunnen verklaren. Dit zien wij vooral in, wanneer wij de bewegingen voorstellen door historische grafieken, waarbij dus langs de horizontale as de tijd wordt afgezet. In fig. 3 zijn een aantal gevallen afgebeeld die zich hierbij kunnen voordoen. $Z$ ij corresponderen met enkele der gevallen van fig. 2 en zijn door de overeenkomstige letter aangegeven. In geval A kunnen alleen endogene bewegingen naar de uiterste waarden van $y$ plaats hebben. Is het stelsel daar aangekomen, dan kan het

5) Vgl. mijn in noot ${ }^{2}$ ) genoend artikel. 
slechts door een storing er weer vandaan komen. Is deze storing betrekkelijk klein - nl. zó dat niet het middelste evenwicht (het labiele) overschreden wordt - , dan keert het stelsel terug naar het bovenste punt. De beweging van bovenste naar benedenste evenwicht kan dus alleen plaats hebben door een uitwendige stoot
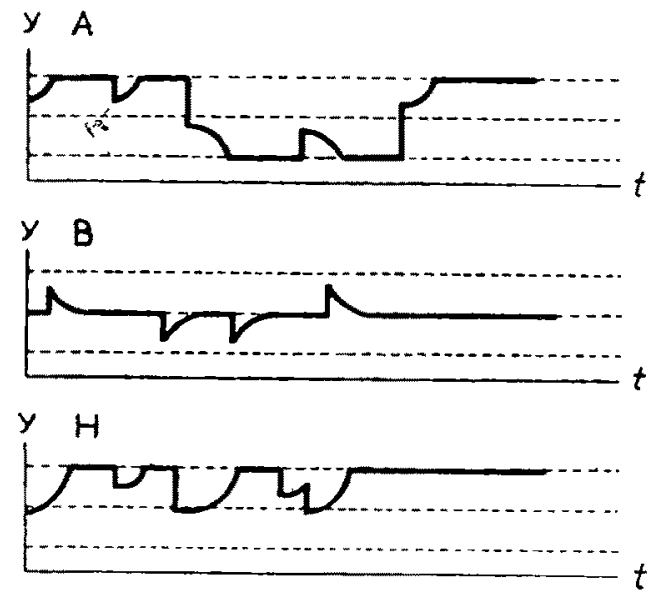

Fig. 3.

die het stelsel onmiddellijk brengt beneden het KEYNES-evenwicht S. Naar analogie kan ook een beweging van het laagste punt naar het hoogste alleen optreden wanneer cen opwaartse stoot optreedt, die het stelsel ineens brengt boven het KeYNes-evenwicht. Dit is green zeer realistische afbeelding van het conjuncturverloop.

In geval B zijn alle endogene bewegingen steeds gericht naar het midclelste evenwicht toe. Slechts door een schok kan hot stelsul een der uiterste posities bereiken, on daarna weer naar het middelste evenwicht te bewegen, hetwelk het niet automatisch overschrijdt. Ook dit is een weinig realistische afbeelding van het conjunctuurverloop.

Wanneer mon zich de moeite geeft, de bewegingstypen vast te stellen die in de overige gevallen mogelijk zijn, zal men steeds bemerken dat soortgelijke, voor een afbeelding van het conjunctuurverloop onbevredigende trekken claarin optreden. Wij komen daarom tot de conclusie dat de eenvoudigste dynamische reacties - nl. die waarbij het inkomen slechts bepaald is door het inkomen in één voorafgaande periode - geen bevredigende verklaring van het conjunctuturverloop kumnen geven. 
10. Wij gaan daarom thans over tot een bespreking van de bewegingen die zich kunnen voordoen, wanneer de dynamische reacties van het op een na ecnvouligste type zijn, zodat de inkomens van twee voorafgaande perioden bepalend $z i j n$ voor het inkomen der beschouwde periode. Een volledige behandeling van deze bewegingen is slechts mogelijk op wiskundige grondslag en zal thans niet worden gegeven. Het betoog zal in de tekst worden geillustreerd door tnige getallenvoorbeelden. De voorstellingswijze van fig. 2, zo nuttig bij het voorafgaande geval, kan ons thans niet meer helpen. Zij zou door een ingewikkelder figuur moeten worden vervangen, die te onoverzichtelijk wordt. Slechts een algebraische behandelingswijze is thans nuttig.

Aangenomen wordt thans dus, dat, zolang geen uitwendige storingen optreden, de waarde yt van het inkomen geclurende de periode $t$ aflangt van de inkomens $y t-1$ en $y t-2$ gedurende de twee voorafgaande perioden volgens een formule:

$$
y_{t}^{\prime}=a y_{t}+1-b y_{t-2}
$$

Wanneer echter de waarde met deze formule berekend uitgaat boven een bepaalde critische waarde (corresponderende met de productiecapaciteit), waarvoor wit in onze voorbeelden het getal 5 hebben aangenomen, dan moet inplaats daarvan voor yt genomen worden deze waarde 5 zelf. Hetzelfde gelelt, wanneer een lagere uitkomst verkregen zou worden dan de waarde van het noodzakelijk minimum, laten wij zeggen - 5. Dan moet - 5 worden genomen. De $y$ wordt hierbij gemeten vanaf het KEYNESevenwicht, dat door het cijfer 0 wordt voorgesteld. Kennelijk is het niet noodzakelijk, dat de afstand daarvan tot het bovenste en onderste punt gelijk zijn. Voor het vervolg van het betoog is deze veronderstelling niet van veel belang en zij kan gemakkelijk vervangen worden door een andere.

Het is begrijpelijk dat de aard der optredende bewegingen afhangt van de getallenwaarde van de coefficiënten $a$ en $b$, evenals in het voorafgaande geval van de marginale bestedingsquote. Verder wordt de beweging natuurlijk medebepaald door de waarden van $y$ voor de eerste twee perioden ( 1 en 2). Zijn deze alsmede de coëfficiënten $a$ en $b$ gegeven, dan ligt de beweging vast.

Een nader onderzoek leert nu dat de volgende bewegingen mogelijk zijn:

I. Bewegingen met periodiek terugkerende keerpunten. Deze kunnen zowel zijn zuiver periodicke als gedcmpt of anti-gedempt- 
periodiek. $Z$ ij vinden plaats om het KEynes-evenwicht als centrum. Zij kunnen nog uiteenlopende amplitude hebben, afhankelijk van de initiale verstoring van het evenwicht. Bij een zuiver periodieke en een gedempte beweging kan zich de beweging geheel voltrekken binnen de grenzen gesteld door de uiterste waarden. Deze spelen dan geen enkele rol bij de beweging; met name zijn zij niet nodig on de beweging tot omkeer te brengen; de omkeer treedt .,uit zichzelf" op, d.w.z. cloor de inhaerente wetmatigheid van de reacties. Ook bij de bewegingen met anti-demping kan dit voor de eerste tijd het geval zijn; doch indien zij lange tijd ongestoord plaats vinden, komt er een moment waarop zij de critische grenzen bereiken. Indien de initiale storing van het evenwicht zo groot is, dat de critische waarde na enige tijd van endogene beweging wordt bereikt, wordt de beweging om deze reden omgekeerd en wel eerder omgekeerd dan zonder het bestaan der critische waarde het geval zou zijn. Hier doet zich de situatie voor, in de meeste conjunctuurtheorieën aangenomen, dat er een afzonderlijke oorzaak voor de omkeer is.

II. Bewegingen naar het Keynes-evenwicht toe gericht. Deze zijn uiteraard voor een verklaring van het conjunctuurverloop van weinig waarde.

III. Bewegingen die op den duur de tendentie hebben zich steeds verder van het KEYNES-evenwicht te verwijderen. Wanneer de begrenzing der $y$-waarden door de critische waarden niet bestond, zou deze soort van bewegingen voor de verklaring van de conjunctuurbewegingen evenmin veel waarde hebben. Door de aanwezigheid dezer grenzen verandert dit echter. Zoodra de beweging de critische waarde heeft bereikt kan zij niet verder. Daarmee is echter niet gezegd dat zij ook omkeert. Het is even goed denkbaar dat zij op de bovenste grenswaarde gefixeerd blijft. Inderdaad leert nader onderzoek weer, dat er hier nog twee typen van bewegingen optreden, n.l.

IIIA. bewegingen die zonder uitwendige aanleiding het bovenste (resp. onderste) punt weer verlaten en

IIIB. bewegingen die het bovenste (resp. onderste) punt slechts verlaten na een uitwendige stoot.

$V$ an de categorie IIIA kan gezegd worden, dat zij zonder het bestaan der critische waarden geen omkeer zou hebben getoond en tengevolge van de aanwezigheid dezer critische waarden die omkeer wel vertonen. Van de categorie IIIB, dat zij ook na de in- 
troductie dezer critische waarden nog niet een verklaring van het omkeerpunt der reële conjunctuurbeweging kunnen geven zonder aan te nemen dat daartoe uitwendige stoten bijdragen.

11. Ten aanzien van deze laatste valt nu nog een belangwekkende verdere opmerking te maken. De grootte van de uitwendige stoot is 11 . niet onverschillig. In elk gegeven model van deze soort - d.w.z. bij elke gegeven stel waarden van $a$ en $b-$ is er een bepaalde ,drempelwaarde" g van de stoot nodig, wil het stelsel zich inderdaad blijvend verwijderen van het bovenste (resp. onderste) evenwichtspunt. Blijft de waarde van de stoot daarbeneden, dan keert de beweging naar het bovenste( resp. onderste) punt terug; voor dergelijke stoten is dus het bovenste punt een stabiel evenwicht. Wanneer echter de stoot groter wordt dan bedoelde drempelwaarde $g$, dan keert het stelsel niet meer terug en is dat punt dus een labiel evenwicht. In de natuurkunde pleegt men een dergelijk evenwicht wel aan te duiden als een metastabiel evenwicht. Een voorbeeld daarvan is een oververzadigde oplossing. Deze bevindt zich binnen enge grenzen van storing nog wel in evenwicht. Doch indien de storing ook maar weinig groter wordt, wordt het evenwicht plotseling verbroken en kristalliseert de oplossing uit.

De in deze modellen beschreven toestand in het bovenste (resp. onderste) punt doet sterk denken aan de beschrijving van HABERLER "). Het stelsel komt in een toestand waarin het gevoelig is voor uitwendige storingen. Het wordt meer en meer waarschijnlijk dat een geringe benedenwaartse storing voldoende is om een cumulatief benedenwaarts proces te ontketenen. Men zou aan deze karakteristiek van HABERLER nog kunnen toevoegen de door KALDOR naar voren gebrachte eigenschappen van het gemengde evenwicht: ook hier stabiliteit voor schokken naar boven, en labiliteit voor schokken naar beneden - zij het dan dat voor dit laatste de drempelwaarde van de schok moet zijn overschreden. De drempelwaarde van de stoot blijkt niet voor alle waarden-combinaties $a$ en $b$ dezelfde te $z i j n$. $Z$ ij bezit voor een aantal gevallen de waarde nul, d.w.z. dat er dan geen drempelwaarde is. Zij kan verder naderen tot de waarde gelijk aan de critische waarde van $y$. In zulke gevallen moet de stoot dus, evenals in de meer elementaire gevallen, het stelsel eerst op het KEYNES-evenwicht terugbrengen,

i) (i. r. Haberler, Prosperity and Depression, Geneve 1039, bv. blz. 347 . 
opdat een overschrijding daarvan kan plaats vinden. In de grote meerderheid der gevallen is echter een waarde tussen $0 \mathrm{cn}$ do critische waarde voldoende on de „weglopende" beweging te ontketenen.

12. Het is van belang te weten voor welke waarden van $a$ en $b$ zich de verschillende mogelijkheden t.a.v. de bewegingen, in het bovenstaande beschreven, voordoen. Fig. 4 geeft hierop het antwoord. Iedere mogelijke combinatie van $a$ en $b$ kan worden weer-

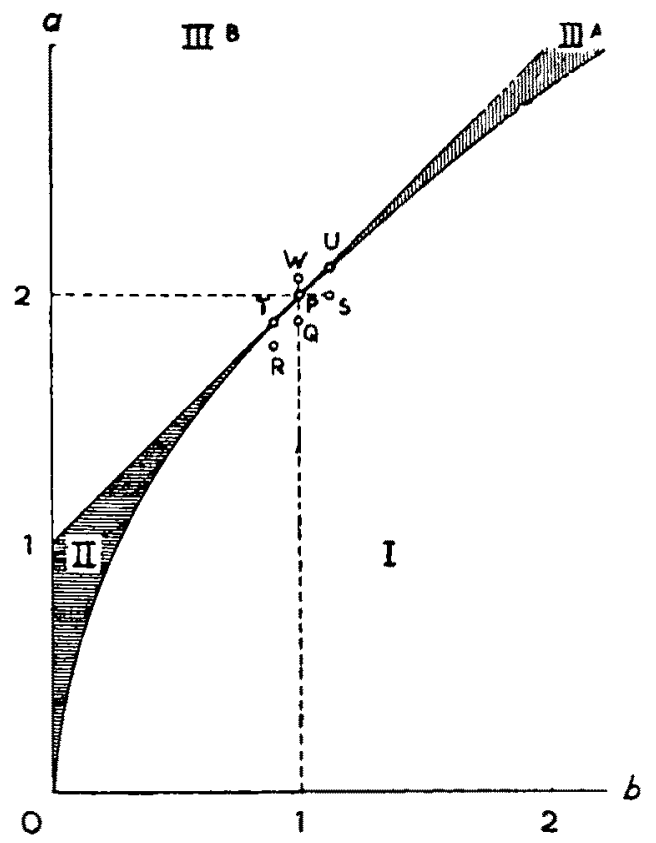

Fig. 4.

gegeven door een punt in een vlak, warin $a$ en $b$ de coördinaten van zo'n punt voorstellen. Wanneer b.v. $b=1$ en $a=2$ is, wordt dat weergegeven door het punt P. Nader onderzoek leert nu, dat het gedeelte van het vlak, waarvoor $a$ en $b$ beide positicf zijn, verdeeld kan worden in vier velden in elk waarvan zich een der genoemde gevallen I, II, IIIA en IIIB voordoen. Aldus is ook in fig. 4 aangegeven. Veld I wordt begrensd door een parabool, veld IIIB ligt boven een rechte lijn. De twee velden tussen deze laatste en de rechte lijn (die n.l. aan de parabool raakt) zijn resp. II en 
IIIA. De vier velden ontmoeten elkaar in het punt $P$, zojuist geroemd, waarvoor $a=2$ en $b=1$ is. Dit punt $\mathrm{P}$ representeert een zeer singuliere situatie; in dat geval is nl. elk niveau van de grootheid y een evenwichtsniveau; het stelsel bevindt zich in indifferent cvenwicht.

13. De verschillende mogelijke bewegingen worden voorts geillustreerd door figuur 5, waarvoor de bewegingen van $y$ zijn uitgerekend in een zestal gevallen en wel telkens met de beginwaarden $y_{1}=0, y_{2}=1$. In figuur 5 zijn bovendien de bewegingen weergegeven die men op analoge wijze kan berekenen wanneer men als uitgangswaarden aanneent $y_{1}=5$ en $y_{2}=5$, d.w.z. wanneer men het stelsel veronderstelt te verkeren in het bovenste punt. De waardeparen $a$ en $b$ die voor deze berekeningen zijn uitgekozen zijn in fig. 4 tevens door punten aangegeven. Men ziet dat de punten $Q, R$ en $S$ in veld I liggen; het punt $T$ ligt in veld II, $U$ in veld IIIA en $W$ in veld IIIB. De gevallen $Q, R$ en $S$ geven resp. cen zuiver-periodieke, een gedempte en een anti-gedempte periodicke beweging to zien. Bij de gekozen uitgangswaarden

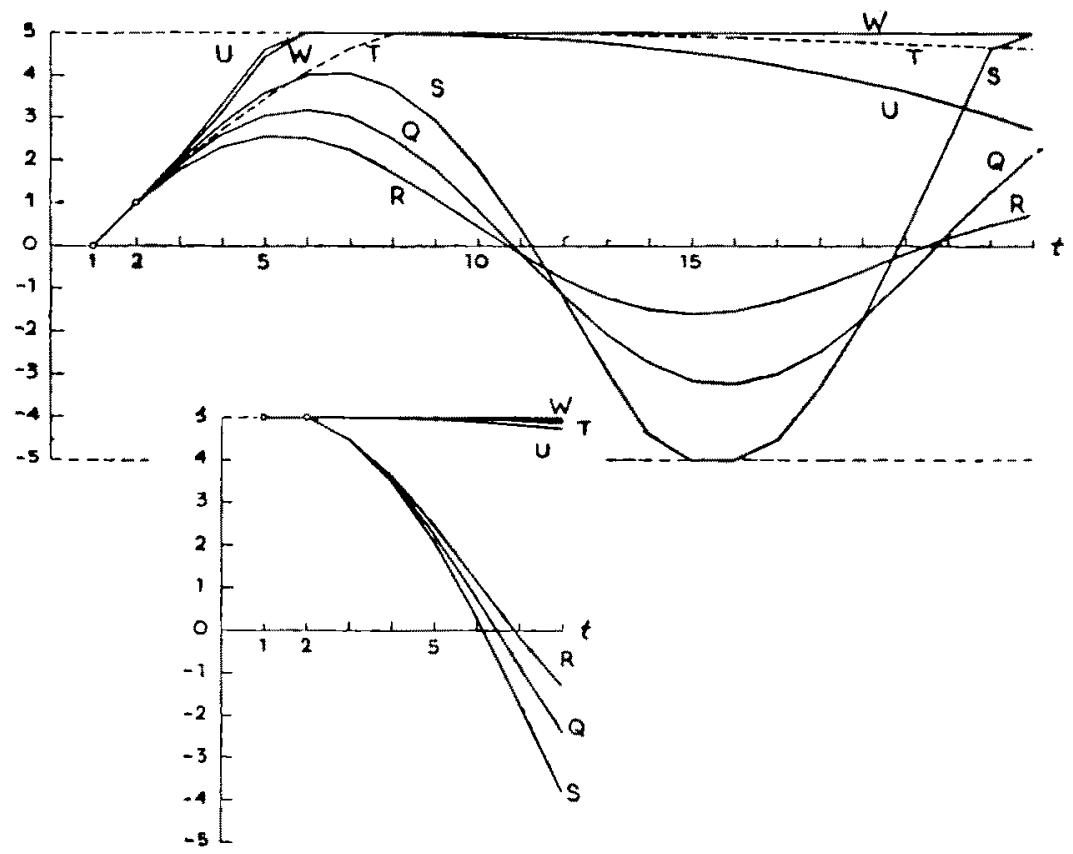

Fig. 5. 
$y_{1}=0$ en $y_{2}=1$ bereiken de eerste twee de critische waarde nooit; in geval $\mathrm{S}$ althans niet bij de eerste top. Zouden wij de uitgangswaarde $y_{2}$ tweemaal zo hoog gekozen hebben, dan zouden alle verdere waarden ook tweemaal zo hoog zijn geworden, voorzover daardoor althans niet de critische waarde $S$ zou zijn bereikt. Daarna zou het verloop anders zijn geweest. In geval $T$ zou men bij verdere berekening een eenzijdige nadering tot het KEYNESevenwicht vinden. In het geval $U$ begint de beweging met ,weg te lopen", doch wordt door de critische waarde niet alleen tegengehouden, doch wederom tot terugkeer bewogen. Hier zou bij verdere berekening het KEYNES-evenwicht worden overschreden en de beweging zich naar het onderste critische punt begeven. In geval $\mathrm{W}$ daarentegen blijft, zonder uitwendige stoot, het stelsel in het bovenste evenwicht.

In een afzonderlijke figuur, fig. 6, zijn tenslotte de bewegingen uitgebeeld, die in geval $\mathrm{W}$ worden uitgevoerd onder de invloed van stoten van uiteenlopende waarden. De drempelwaarde bedraagt in dit geval 0,9. Men ziet inderdaad dat bij een schok 0,5 en 0,8 de beweging tot het uitgangspunt terugkeert; bij een schok 1,0 en 1,5 echter niet.

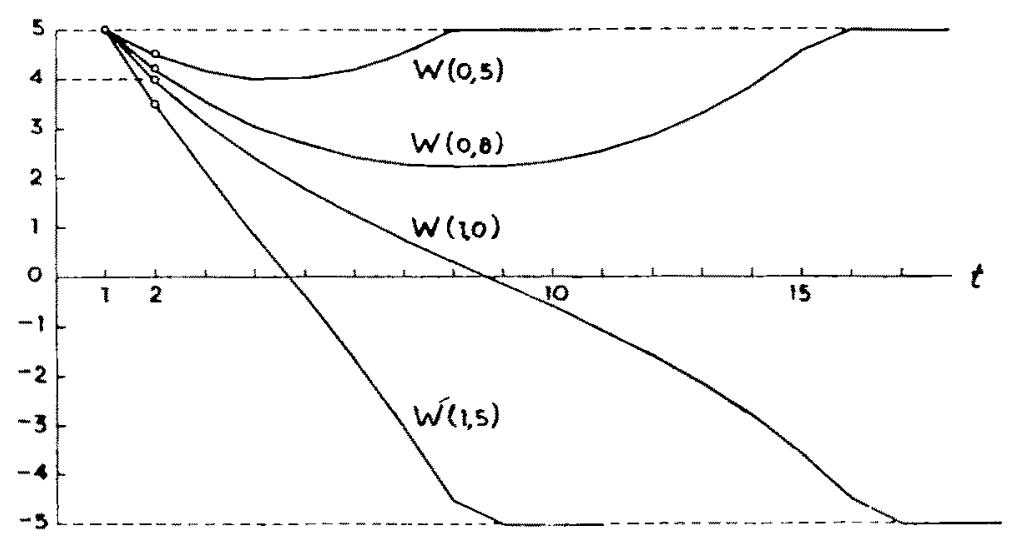

Fig. 6.

14. Wij hebben thans voldoende kennis vergaard on een antwoord te kunnen geven op de vraag, in de aanhef gesteld. Onder de bewegingen die kunnen worden uitgevoerd wanneer het economische stelsel het thans beschreven iets ingewikkelder karakter bezit - waarbij aanwezig zijn een KEYNES-punt en twee 
GoUdRIAAN-punten, terwijl de hoogte van het inkomen afhangt, gedurende een endogene beweging, van de inkomens in twee voorafgaande peroiden -- zijn er verschillende die het karakter der conjunctuurbeweging vrij goed benaderen. Van de hier besproken gevallen $Q, R, S, T, U$ en $W$ voldoet eigenlijk alleen $T$ niet. Verder beschrijven alle stelsels, indien men het voortdurend optreden van storingen aanneemt, min of meer periodieke bewegingen, die zich in elk geval in de zône tussen de twee GoudriaAN-punten afspelen. Wat is nu de rol van de evenwichtspunten in elk dezer stelsels?

In geval $Q$ zijn de GoudrIAAN-punten geen evenwichtsstanden; als het stelsel in die stand gebracht zou worden, zou het deze vanzelf weer verlaten. Hetzelfde geldt voor de gevallen $R, S$, T en U. In geval W daarentegen zijn de GoudrIAAN-punten dit wel. In elk der gevallen is het KEYNES-punt een evenwichtspunt, doch in de gevallen $\mathrm{S}, \mathrm{W}$ en $\mathrm{U}$ een labiel evenwichtspunt, dus een oneigenlijk evenwichtspunt. In de gevallen $R, Q$ en $T$ daarentegen is het evenwicht semi-stabiel resp. stabiel. Daaruit zien wij dat het nooit voorkomt - in de hier beschouwde klasse van modellen, waarbij het inkomen afhangt van de inkomens in twee voorafgaande perioden - dat de GoudriaAN-punten en het KEYNESpunt tegelijk eigenlijke evenwichtspunten zijn. Deze twee mogelijkheden sluiten elkaar dus inderdaad uit. Toch zijn zij niet ver van elkaar verwijderd. Wij wezen er reeds op dat alle beschouwde velden in fig. 4 elkaar in punt $\mathrm{P}$ ontmoeten. $\mathrm{Er}$ is dus cen geleidelijke overgang van de eene mogelijkheid naar de andere. Het is een kwestie van quantiteiten, welke der mogelijkheden met de realiteit overeenstemt; door meting is dit uit te maken. De standpunten zijn wel verschillend, doch kunnen willekeurig weinig van elkaar verschillend zijn.

15. Wat is de economische betekenis van de getallenwaarden van $a$ en $b$ ? Dit hangt uiteraard af van de theorie waarop men de relatie $y_{t}=a y_{t-1}-b y_{t-2}$ wil bouwen. Eén mogelijke theorie is de volgende.

Laten de uitgaven $y_{t}$ afhangen van het inkomen $y_{t-1}$ en van de inkomensstijging $y_{t-1}-y_{t-2}$, d.w.z. Iaten wij de relatie schrijven in de vorm

$$
y_{t}=(a-b) y_{t-1}+b\left(y_{t}-1-y_{t}-2\right)
$$

Dan stelt $a-b$ voor de marginale uitgavequote (in de bovenEcon. 1943. 
gedefinieerde zin) t.o.v. het statische inkomen, $b$ de marginale uitgavequote van de inkomensstijging. Het is waarschijnlijk dat $a-b$ zich bevindt in de nabijheid van de waarde 1 ; dit betekent echter juist dat het punt dat het stelsel afbeeldt in fig. 4 ligt in de nabijheid van de rechte lijn die veld IIIB scheidt van de drie overige velden. Men zou dus niet verbaasu behoeven te zijn, door statistische meting in de buuit te komen van de verschillende door ons aan de berekeningen ten grondslag gelegde punten.

Een cnkele poging tot een dergelijke statistische meting, door schrijver dezes verricht, moge hier worden vermeld. $Z$ ij had betrekking op het conjunctuurverloop in Groot-Brittannie in de periode 1870-1914. Het onderzoek werd uitgestrekt tot de relaties tussen een groot aantal voor het conjunctummechanisme relevante verschijnselen. De totale uitgaven, gesplitst naar verschillende categorieën, werden beschomwd als afhankelijk van een aantal uiteenlopende verschijnselen, waaronder het nationale inkomen. De overige verklarende verschijnselen werden op hun beurt verklaard uit weer andere enz. Dit proces werd voortgezet totdat alle daarbij beschouwde grootheden waren teruggebracht tot het nationale inkomen op enig vroeger tijustip. waardoor een relatie van de hierboven steeds gebruikte vorm werd bereikt die geacht kan worden de veroorzaking der endogene bewegingen weer te geven. Daarbij werden coëfficiëntun $a$ 'n $b$ gevonden van resp. 1,27 en 0,60 . Het daarmee corresponderende punt in fig. 4 ligt dichter bij de oorsprong dan de in onze voorbeelden gekozen waarden. De endogene beweging die er mee correspondeert is een periodieke beweging van gedempt karakter. Wanneer hut stelsel onderworpen is aan voortdurend weerkerende storingen, zal echter toch een beweging worden uitgevourd die eun ongedempte verschijningsvorm heeft. Er zijn ook overigens wel enige argumenten aan te voeren voor de zienswijze dat de modellen met periodicke endogene beweging de werkelijkheid benaderen. Zo b.v. dat men maar zelden heeft waargenomen dat de stand van volle bezetting lang achtereen werd gehandhaafd; en dat in ettelijke conjunctuurtoppen de volle bezetting geenszins werd bereikt. Doch onze beschouwingen hadelen voornamelijk tot doel om te doen zien dat in de grond de verschillen tussen de verschillende besproken modellen minder groot zijn dan men op het cerste gezicht zou denken en in elk geval dat de verschillende modellen in elkaar overgaan. 
16. Resumeren wij tenslotte de voornaamste punten van ons betoog. De plaats van economische evenwichten, voorzover zij bestaan, kan worden bepaald met statistische hulpmiddelen. Hun aard kan echter slechts worden vastgesteld met dynamische methoden, aangezien die aard aflangt van de bewegingen van het beschouwcte stelsel na een aanvankelijke verstoring van het evenwicht. Er is aanleiding om te onderscheiden tussen de volgende soorten: stabiele, labiele, indifferente, semi-stabiele, gemengde en meta-stabiele evenwichten. Het maakt voor de aard der cndogene bewegingen veel uit of men aanneemt dat de toestand in een bepaalde eenheidsperiode wordt bepaald door de toestand in één voorafgaande, dan wel in twee (of eventueel meer) voorafgaande perioden. Met de eerste veronderstelling kan men geen zeer aanvaardbare modellen van de conjunctuurbeweging construeren, daarentegen wel met de laatste. Wanneer men veronderstelt dat de toestand in twee voorafgaande perioden voor de daaropvolgende periode bepalend is kan men zowel modellen construeren met een evenwichtspositie in het midden als modellen met twee evenwichtsposities waartussenin zich de cumulatieve processen afspelen van beneden naar boven of van boven naar beneden. Ofschoon deze modellen elkaar uitsluiten, staan zij toch niet ver van elkaar af: zij gaan in elkaar over. Of het ene dan wel het andere zich voordoet is een kwestie die afhangt van de getallenwaarden van enige coëfficiënten, waarbij in het bijzonder van belang zijn de marginale ,propensity to spend" t.a.v. het statisch inkomen en t.a.v. inkomensvermeerderingen (of inkomens uit speculatie). 